\title{
Introduce Soft Tennis Sport in West Sumatera
}

\author{
Pitnawati*, Damrah \\ Sport Education Program \\ Faculty of Sport Science \\ Padang State University \\ Padang, Indonesia \\ pitnawati@fik.unp.ac.id*,damrah@fik.unp.ac.id
}

\begin{abstract}
The purpose of this analysis is to introduce and popularize tennis sports to people throughout West Sumatra in order to participate in tennis championships at both student, regional, and national/international levels. This research is descriptive qualitative that involved five samples. The source of the data is in the form of observations, interviews, and documentation collected in the field about the process of tennis in West Sumatra, through the scope of coaching by reviewing questionnaire data, the results of interviews, observation, and documentation. The results showed that the number of Pengcab Pesti participation that had been appointed following the Pengprov Pesti Sumbar Decree was increased, namely as many as 12 Pengcab Pesti $(36 \%)$ of the 33 planned areas. At the same time, the number of athletes increased from 36 athletes to 120 athletes. Some of the reasons for the contribution of regions to managing and participating in the planned Championship are potential human resources to develop skills in the field of soft tennis and the high desire of the community to advance regional sports, exceptionally soft tennis at the national level. Besides, soft tennis skills are not much different from tennis, so learning soft tennis movements is not so difficult to master.
\end{abstract}

Keywords tennis, soft tennis

\section{INTRODUCTION}

Sports have an impact on the quality development and productivity of one's work. Through exercise can have a good quality of life in the appeal that does not do the activity. Exercise is a series of regular, well-planned physical movements to nurture motion and enhance mobility. In addition, exercise is also increasingly needed by human beings in this increasingly complex and automated life, so that people can retain their existence spared from various disorders or dysfunction as a result of a lack of motion sickness [1]. Exercise precisely and correctly will be an important factor that is very supportive for the development of self-potential. The health, physical fitness and personality traits of the superior sportswear are a very supporting factor for the development of human selfpotential, and through education, recreational activities, and other appropriate sports and Really. However, we know together with the current conditions of community participation to the sport is decreasing with the reason of space limitation, work activities are crowded, as well as the sport conditions itself which facilities develop and in a costly taste By some level of middle society down. In this case, the community through social institutions and
Governments should see this phenomenon by trying to creatively raise the form of sports that can be reached and done by all walks of life regardless of social status.

The results of the previous study were obtained by the conclusion that the training of tennis that is given in a structured and well managed will be able to help problems coaching achievements in the area especially sporting achievements Tennis. Because of the many seeds - tennis sportspeople in elementary school, it needs to be welldirected to overcome the problem of coaching local tennis sports and it is also possible for other sports branches. The use of existing land or field, can be effectively utilized to make tennis sports through "tennis play and Stay" and "mini tennis". The cooperation of all parties ranging from schools, teachers, students and parents and communities and governments is a very important part of improving in order to develop talents, students ' interest in specific sports branches [2].

Soft tennis sports are a newly developed sport and have a recreative level that is almost identical to that of tennis and it can be used in the tennis field that has been available in each area. The availability of open space sports is the most important part for the establishment of a conducive atmosphere in sports culture. The good sports culture is in complete scope i.e. (1) Sporting achievements, (2) educational sports, (3) Community sports or recreational sports [3]. Ketersedianya open space or open space needed around us is now a lot of unbalanced with the number of people's desire to exercise activities. The activities of car free day, healthy Friday activities, healthy Street seniors, fitness gymnastics is positive for promote sports activities that are maintaining the quality of public health through mass and open activities and cheap can be in Do all the good young to old people. In this case, the game is included in the elements of three sports pillars namely achievement sport, educational sports (educational sport) and recreation sport. Soft tennis as a performance sport, requires a progressive and ongoing training program through a competent trainer in their field, so that in achieving the target of the soft tennis coaching will be very easy if and can run well. Soft tennis as a new sport, but has a great prospect of developing talent and career as well as the future of the community. Some data have been obtained that soft tennis athletes have been in the international event, namely Sea Games 2011 in Palembang gained 7 gold 
medals, Asean Games 2014 in China gained 1 silver medal, and Asian Games 2018 in Palembang won 1 medal Silver and 2 bronze medals (PP. Pesti, 2019). From these results it can be concluded that soft tennis sports have the same roles and tasks as other sports branches. Therefore, very reasonable soft tennis sports need to be spread throughout the region, especially throughout West Sumatera, because West Sumatera region is very potential in developing and creating achievements in this field of sport. Soft tennis includes a fairly interesting and easy-to-learn game sport for both children, teenagers and adults and can be done in a not so wide field, with simple and inexpensive equipment, so that people can Do it anywhere. This led to the need for the introduction or socialize of Soft tennis sports as a sports that are in the same childhood as children and teenagers and adults. Socialize sport has the meaning of embedding sports in the joints of society, both in value and habit. This sentence directly and indirectly try to attract the attention of the public will exercise. Further, sportspeople have a deeper meaning to embed sports activity in the community.

The marketing of sporting activities in the community is a major fundation in the National Sports System (SKN), in addition to improving the health and fitness of society, through the increase of the community's sporting culture can bring Athlete's seed. Law No. 3 year 2005 on national sports system governs all stakeholders together to build sports both private and government. "Through the culture of society we can recognize and nurture an athlete from an Amateurian to an elite athlete in the future. Therefore, the process of culture cultivation needs to be continuously improved and developed into villages throughout Indonesia [4], "said the Minister of Youth and Sports (Menpora) Imam Nahrawi in a greeting at the National Sports Day Ceremony (Haornas), Wednesdays (9/9) [5]. The supply of particular sports branches, needs to be done throughout the region in Indonesia, because the source of national athletes, the average many come from areas that have talent-and interests are still stored, therefore through socialization and introduction of sports will be able to contribute to the advancement of performance Sports in Indonesia in addition to improving the quality of physical education and exercise in schools.

Introducing soft tennis Sports to areas in West Sumatera can be done by providing the equipment and provisions needed in the game, so that each region can understand and give to his children in the form of Training according to their respective level of ability. Soft tennis games can be played individually, paired or in a team form using certain rules "Matches can be played as singles, men or women doubles and mixed doubles, as in regular tennis. Singles matches are usually played by a one set, best of seven games system (the player who has won four games wins the match). Doubles are played by a one set, best of nine system ( the pair who has won five games first wins the match)" [6]. The difference is with tennis, located on rackets and balls and game rules. The pack is lighter and smaller, the ball is gembosses and lighter, and the more simple the count (ASTF, 2011). With this condition, it is expected that everyone can easily recognize and learn and develop it into a programmatic form of training. The purpose of this preparation is for soft tennis sports to be known and developed by the people of West Sumatra, through an organsisasi that has been established and recognized by KONI each region as one of the target sports branches.

\section{RESEARCH METHODS}

The method used in this research is qualitative, which is through the processing of field data in the form of statements or data collection results that have been prepared by researchers. Instruments used in the form of socialization, observation, interview and documentary evidence collection in the field about soft tennis supply through SK Pengprov Pesti Sumbar and its participation in the planned regional championships by Pengprov Pesti Sumbar. The data sources used are members given mandate in each region and people who support the existence of soft tennis in each area [7]. Research plan made is the activity of the implementation through training seminars and socialization of games and the workshop and coaching Clinic, after the program is conducted for six months, then a comparison of regional participation In his participation on the regular agenda of Soft Tennis district championships. If the positive area participation is able to participate in activities conducted by the provincial Pesti, then the marketing or socialization activities have been stated to go well and vice versa if negative area participation (not follow) means that the residency and socialization activities failed (unsuccessful).

\section{RESULTS AND DISCUSSION}

The results of this research are related to regional participation in soft Tennis district championships. The area that participated in this Championship is 14 areas namely 1 ) Kota Padang, 2) Kab. South Commissioner, 3) district. South Solok, 4) City of Solok, 5) City of Pariaman, 6) district. Padang Pariaman, 7) Kab. West Pasaman, 8) District Pasaman, 9) City Payakumbuh, 10) District 50 Cities, 11) Mentawai District, 12) district. Stone Cage, 13) Sawahlunto, 14) Agam district. While the area that has not been called is 5 areas, namely 1) district Solok, 2) City of Bukittinggi, 3) Dhamasraya District, 4) Sijunjung District and 5) Padang Panjang City. The result is the number of clubs increased by $73.68 \%$. The number of growth athletes after the supply in 14 counties and cities was 167 athletes and considerably increased from the previous year, i.e. the average of only 5 athletes of each region. The improvement is approximately $150 \%$. For more details can be seen from the picture below some reasons the contribution of the area following the Championship is the motivation and level of ability of the area and children in achieving achievements. This means the level of regional participation in the 
Championship increased. The average area wants to acquire achievements, because all the areas have the opportunity and skill levels are relatively equal, namely acquiring knowledge and skills levels of new sports, so that every region and athlete does not exist Who feels it has advantages. In addition to athletes and areas with achievements will have an impact on the progress of the sport in their respective regions and this is the forerunner of athletes who will be participating in regional, regional, national and international championships. For more details can be seen from the following image:

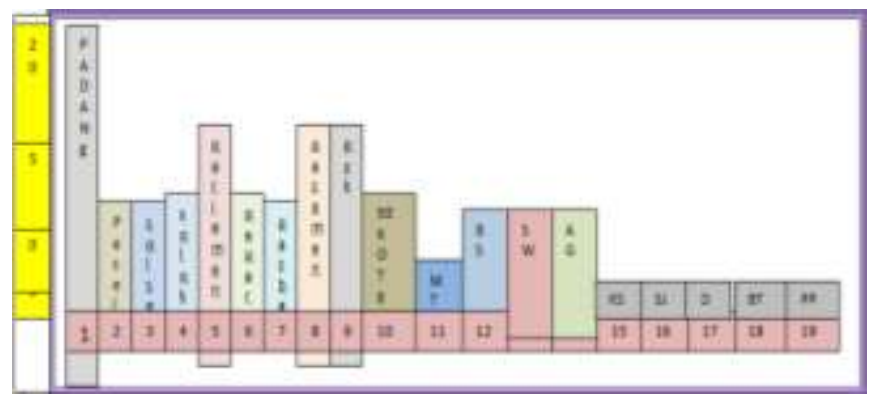

Figure 1. Results of Soft Tennis Sports in West Sumatera

With the results of this research, it is hoped that the development of soft tennis sport will be increased, by involving all existing districts in the district and cities in West Sumatera. It is already done by developed countries such as Japan and Korea, "Soft tennis is essentially tennis with a softer, lighter, inflatable ball and, optionally, lighter, more loosely strung racquets. Soft tennis is most popular in Japan, where it was first played in 1884 and now comprises roughly $40 \%$ of the tennis played. It's also popular in Korea and Taiwan and growing all over the world, with some two dozen national federations and associations from Peru to Hungary [8]. From the explanation above, can be informed that the progress of soft tennis sports in West Sumatera will be able to give effect in the progress of soft tennis nationally and internationally.. The difference between soft tennis and tennis can be explained through the following explanation:Most of the rest of the rules of soft tennis are the same as regular tennis. Here are the more significant exceptions:

- The net is the same height, $1.07 \mathrm{~m}$ or $3^{\prime} 6^{\prime \prime}$, all the way across the court; it's not 6" lower in the middle as in regular tennis.

- A match in singles consists of a single set completed by winning four games (best of seven). A doubles match is won with five games (best of nine). The number of games in a match might be so much fewer than in regular tennis because soft-tennis points are expected to last much longer.

- In soft tennis doubles, the serving rotation between teams is the same as in regular tennis, but the partners on a team take turns serving two consecutive points throughout the game.

- Instead of tie-breaks, soft tennis uses a "final game" at 3 -all in singles or 4-all in doubles. In the final game, singles players or doubles teams take turns serving two points at a time, and they change ends after the first two points and then after every four [9].

To get optimal results in a particular sports branch including this soft tennis, much needed mastery of the game rules. The rules of the game and the match must be international meaning something given to the community based on rules that have been issued by the Sports Federation respectively.

\section{CONCLUSION}

The conclusion of the study was that by the broadcast it demonstrated a good growth in the regional participation of soft Tennis championships in West Sumatera. This research is expected to be used for followup reference as a step to develop the game Soft tennis in the future, making it easier on the next development of the nursery and construction of soft tennis achievements. In the development of the sport that has not been in demand this, there is a need for cooperation of various parties that is the party of KONI, Dinas Education, Dinas Youth and Sports and the local government and private sector to jointly run the program, Seedlings and coaching.

\section{REFERENCES}

[1] Giriwijoyo, H.Y.S. Santoso. "Ilmu Kesehatan Olahraga". Bandung, PT.Remaja Rosdakarya. 2012. pp. 23-45.

[2] D., Damrah. P. Pitnawati, \&, E. Erianti. "Pelatihan tenis terhadap guru Pendidikan Jasmani Sekolah Dasar Negeri di Kota Padang". J. Widya laksana, Vol. 8 No.2, 202-207. July 2019

[3] K, Agus. "Pembangunan Olahraga Untuk Kesejahteraan Rakyat dan Kejayaan Bangsa”. Surakarta: Yuma Pustaka. 2012.pp.66-78.

[4] Undang-Undang Republik Indonesia Nomor 3 Tahun 2005 tentang Sistem Keolahragaan Nasional. Jakarta: Biro Humas dan Hukum Kementerian Negara Pemuda dan Olahraga Republik Indonesia. 2007.pp.12-23.

[5] www.Berita Olahraga terkini.com.2015

[6] H. Vegda. "Rules of Soft Tennis", Published by:Amateur Soft Tennis Federation of India (ASTFI). 2011.pp.55-58

[7] Jeff Cooper. "Soft Tennis". Live About is part of the Dotdash publishing family, Japan. 2019.pp.10-23.

[8] Damrah. "Peraturan permainan Soft Tennis Indonesia". PP Pesti, Jakarta. 2013.pp.12-43.

[9] Shih-Tsun Chang, Yen-Hsiu Liu, Jiahn-Shing Lee, Lai-Chu See. "Comparing sports vision among three groups of soft tennis adolescent athletes: Normal vision, refractive errors with and without correction". Article in Indian Journal of Ophthalmology 2015.pp.43-55. 